\title{
Demografi Diabetes Melitus Tipe-I pada Anggota Ikatan Keluarga Penyandang Diabetes Anak dan Remaja (IKADAR)
}

\author{
Endang Triningsih Faisal \\ Bagian Ilmu Kesehatan Anak, Kelompok Kerja Endokrinologi Anak \\ Rumah Sakit Anak dan Bunda Harapan Kita, Jakarta
}

\begin{abstract}
Abstrak
Diabetes melitus (DM) tipe-1 merupakan penyakit kronik karena ketergantungan insulin dari luar tubuh. Dalam pengobatan penyakit tipe ini perlu pegawasan yang ketat dan membutuhkan kesadaran dan pengertian pasien dan orangtua. Ikatan Keluarga Penyandang Diabetes Anak dan Remaja (IKADAR) merupakan perkumpulan anggota pasien DM, sehingga dapat saling membantu. IKADAR belum banyak dikenal luas. Dari data 167 anggota IKADAR, ditemukan perempuan lebih banyak dari laki-laki. Hanya 99 anggota yang dapat ditelusuri melalui telepon, Mayoritas bertempat tinggal di Jabotabek, 66 anggota berobat dengan biaya sendiri, 54\% berkisar umur 510 tahun. Pengertian tentang penyakit DM ditemukan 22,2\% belum mengerti penyakit maupun penanganan DM, namun sebagian besar pasien tersebut menyatakan IKADAR berperan bagi pengobatan. [MKB. 2010;42(2):82-5].
\end{abstract}

Kata kunci: Diabetes melitus tipe 1, demografi, anak

\section{Demography Study Diabetes Mellitus Type 1 of Diabetes Mellitus Family Member}

\begin{abstract}
Diabetes mellitus (DM) is classified as a chronics disease due to its property of external insulin dependency. Intensive monitoring, as well as awareness and good understanding from the patients and their patients are prerequisite to achieve excellent result in the management this disease. Ikatan Keluarga Penyandang Diabetes Anak dan Remaja (IKADAR) is an association of DM patients together with their family which aims to facilitate the members to help and share each other. Unfortunately, IKADAR hasn't been widely known. Currently IKADAR has 167 members but only 99 members could be reached by telephone, the majority time in Jabotabek, sixty six had their medication paid out of pocket, fifty-four percent were 5-10 years of age. As many as $22.2 \%$ found to having no comprehensive understanding about DM and the management. The majority of patients suggest that IKADAR play a big role in their treatment.
\end{abstract}

[MKB. 2010;42(2):82-85].

Key words: Type 1 diabetes mellitus, demography, children

Korespondensi: dr. Endang Trinigsih Faisal, Sp.A(K)., Kelompok Kerja Endokrinologi Anak dan Remaja, Rumah Sakit Anak dan Bunda Harapan Kita, Jakarta. Telp. (021) 5668284, Hp: 0811807635 


\section{Pendahuluan}

Diabetes melitus (DM) merupakan penyakit yang ditandai dengan adanya kenaikan kadar gula darah (hipergilkemia) kronik. ${ }^{1-6}$ Diabetes melitus adalah penyakit yang ditandai dengan hilangnya berat badan, poliuria, polidipsi, dan polipagia. ${ }^{7,8}$ Pada penyakit ini kekurangan insulin sehingga terjadi peningkatan kadar gula darah dan menimbulkan perubahan metabolisme protein dan lemak. DM tipe-1 mempunyai ketergantungan insulin. Pada umumnya anak dan remaja adalah DM tipe- $1,{ }^{1-3}$ sehingga perlu pegawasan yang ketat, serta membutuhkan kesadaran dan pengertian pasien dan orangtua.

Ikatan Keluarga Penyandang Diabetes Anak dan Remaja (IKADAR) merupakan perkumpulan anggota pasien DM, sebagai wadah silaturahmi para keluarga diabetisi. IKADAR ini suatu forum komunikasi antar keluarga diabetisi agar dapat saling membantu kesulitan para anggota dan memberikan informasi baru, serta forum mediasi yang menyuarakan kepentingan diabetisi pada masyarakat. Kegiatan IKADAR, yaitu mengenal dokter endokrinologi sehingga mempermudah dalam berkomunikasi anak, belajar kemandirian anak, pengenalan obat insulin, cara pemantauan gula darah, dan diet pada anak diabetisi .'

Pasien DM tipe-1 membutuhkan insulin seumur hidup, perlu pengertian dan kepatuhan pasien, serta dukungan orangtua dan keluarga. Hal ini sangat berarti bagi pasien, sehingga menjadi percaya diri dan mandiri dalam penanganan $\mathrm{DM}{ }^{9}$

Penelitian ini bertujuan untuk mengetahui gambaran dan peran IKADAR terhadap anak penyandang DM tipe-1 yang menjadi anggota IKADAR.

\section{Metode}

Subjek penelitian dikumpulkan dari buku register DM yang terdaftar dalam IKADAR, kemudian melakukan kuesioner pada orangtua/anggota melalui wawancara telepon. Data ditampilkan dalam bentuk gafik batang dan diagram.

\section{Hasil}

Seluruh anggota IKADAR berjumlah 167 orang yang terdiri dari 67 laki-laki $(40,1 \%)$ dan 100 perempuan (59,9\%). Sebaran umur anggota saat didiagnosis DM, terbanyak pada kelompok umur 5-10 tahun (54\%), kemudian kelompok di atas 10 tahun (36\%), dan di bawah 5 tahun (10\%), terlihat pada Gambar 1 dan 2.

Dari buku register, terdapat 158 anggota yang tersebar di beberapa kota, sedangkan sembilan anggota tidak mempunyai alamat jelas atau tidak ditemukan data. Kebanyakan anggota tersebar di Jabotabek (Depok termasuk Jabotabek) sebanyak

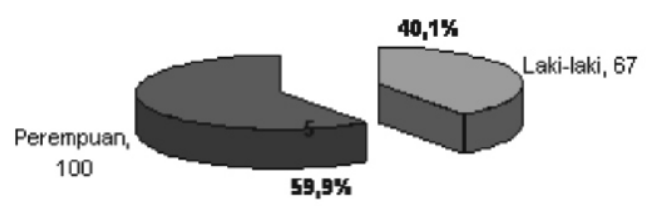

Gambar 1 Sebaran Pasien Anggota IKADAR Berdasarkan Jenis Kelamin

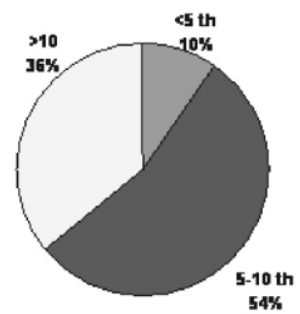

Gambar 2 Sebaran Umur Anggota IKADAR Saat Diagnosis DM

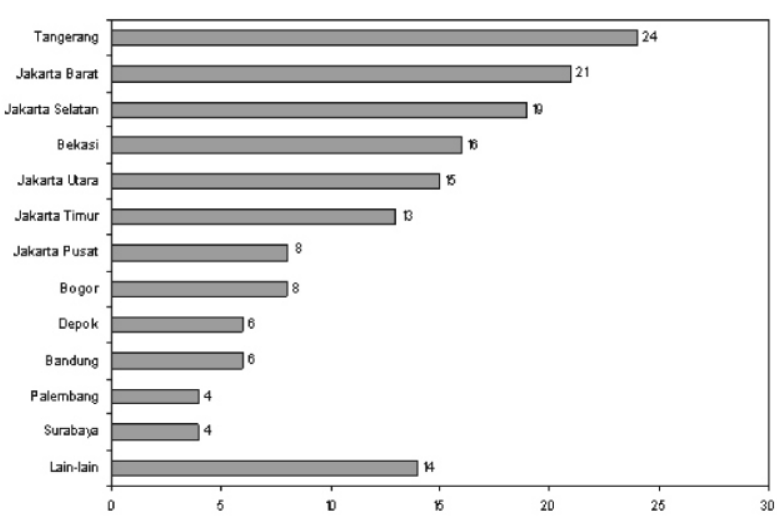

Gambar 3 Sebaran Anggota IKADAR Berdasarkan Tempat Tinggal

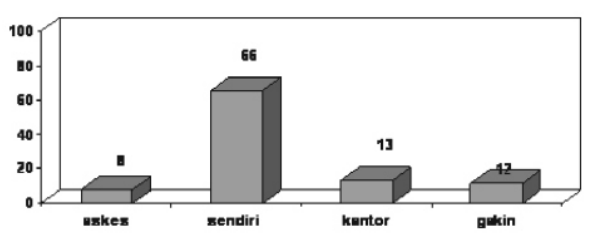

Gambar 4 Sebaran Anggota IKADAR Berdasarkan Biaya Pengobatan 

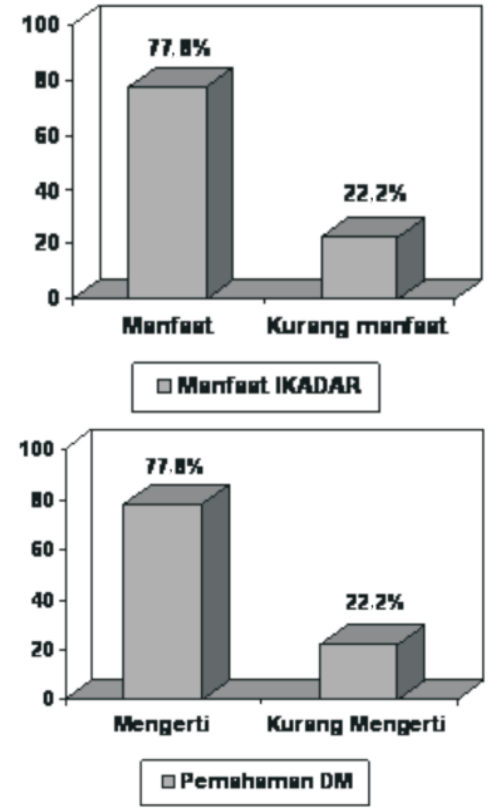

Gambar 5 Sebaran Manfaat IKADAR dan Pengertian Pasien Terhadap DM

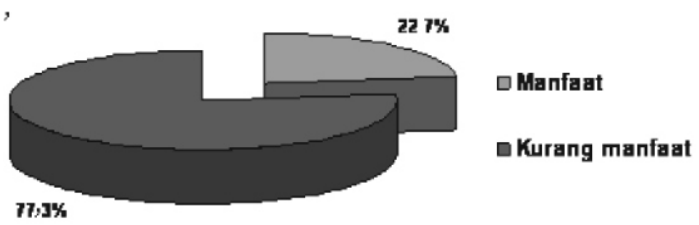

Gambar 6 Hubungan Anggota yang Kurang Paham Tentang DM dengan Peran IKADAR

130 pasien dan 28 pasien di luar Jabotabek. (Gambar 3).

Kunjungan terbanyak berasal di daerah Tanggerang (24 anggota). Tempat tinggal di luar Jabotabek ditemukan 28 anggota, terbanyak dari Palembang, Surabaya, dan Bandung.

Kebanyakan dari anggota IKADAR berobat dengan biaya sendiri yaitu 66 anggota, dibiayai oleh kantor 13 anggota, GAKIN 12 anggota, dan askes 8 anggota. (Gambar 4 ).

Anggota yang menyatakan peran IKADAR kurang bermanfaat sebanyak 22 anggota $(22,2 \%)$, serta yang menyatakan bermanfaat sebanyak 77 anggota (77,8\%). Anggota yang menyatakan IKADAR kurang bermanfaat adalah yang berobat dengan biaya sendiri. Dari wawancara terhadap anggota terdapat $22(22,2 \%)$ anggota menyatakan kurang paham tentang DM dan komplikasinya. Wawancara ini dilakukan terhadap orangtua dan pasien DM yang bersangkutan.
Gambar 6 menunjukkan dari 22 anggota yang menyatakan IKADAR kurang paham tentang DM, dan 17 anggota $(77,3 \%)$ yang menyatakan bermanfaat, sedangkan sisanya hanya lima anggota $(22,7 \%)$ menyatakan tidak.

\section{Pembahasan}

Anggota IKADAR lebih banyak perempuan $(59,9 \%)$ dibandingkan dengan laki-laki $(40,1 \%)$, data ini sesuai dengan hasil penelitian Asin dkk. ${ }^{10}$ sedangkan pada penelitian sebelumnya, bahwa perempuan lebih banyak dibanding laki-laki. ${ }^{10}$ Travis dkk. ${ }^{8}$ meneliti DM di Amerika metemukan bahwa anak perempuan dua kali lebih banyak dibanding laki-laki dan tersebar di beberapa kota. Pada Gambar 2 menunjukkan bahwa 28 anggota berdomisili di luar Jabotabek, dan terbanyak di Bandung, Surabaya, dan Palembang. Daerah tersebut terdapat dokter spesialis endokrinologi anak, sehingga diagnosis serta pelayanan lebih terarah.

Sebaran umur terbanyak pada umur 5-10 tahun (54\%). Hal ini sesuai dengan data dari rumah sakit bahwa terdapat dua puncak insidens DM tipe-1 pada anak, yaitu pada umur 5-6 tahun dan 11 tahun. ${ }^{11}$

Kebanyakan anggota IKADAR berobat dengan biaya sendiri $(77,8 \%)$, maka hal ini akan mempengaruhi ketaatan dalam pengobatan, terutama pada pasien kurang mampu, yang tidak menggunakan GAKIN.

Peran IKADAR dikatakan bermanfaat, bila anggotanya bertambah pengetahuan tentang DM dan komplikasinya, membantu dalam pengadaan obat, dan lebih percaya diri. Terdapat 22 anggota menyatakan IKADAR kurang bermanfaat, adalah anggota yang berobat dengan biaya sendiri dan berobat ke dokter pribadi.

Tidak ada korelasi antara manfaat IKADAR terhadap pengertian anggota terhadap DM, karena dari $22,2 \%$ anggota yang kurang paham mengenai DM, mayoritas anggota menyatakan bermanfaat, kemungkinan karena pendidikan atau sosialisasi yang kurang tentang DM.

IKADAR sangat berperan dalam memantau perkembangan anak DM, juga sebagai wacana berkomunikasi, penyediaan alat, dan pemantauan kedaruratan. Berdasarkan data anggota IKADAR, beberapa anggota tidak dapat dimintai pendapat karena tidak aktif atau sudah dewasa dan pindah 
berobat ke dokter speasialis penyakit dalam. Sampai bulan Desember 2006 terdapat 16 anggota IKADAR yang sudah berusia lebih 18 tahun dan berobat ke dokter spesialis penyakit dalam.

Dari penelusuran ditemukan tiga anggota meninggal, dan dua anggota meninggal karena penyakit lain (lupus dan tumor otak), serta satu anggota meninggal karena ketoasidosis (KAD) yang dirawat di rumah sakit daerah.

Peranan IKADAR tidak akan menggantikan peranan dokter dalam menangani perawatan DM, tetapi organisasi ini diharapkan dapat mengambil peran dalam rangka membantu kelancaran proses perawatan DM anak dan remaja.

Peran IKADAR bermanfaat pada DM tipe-1, karena merupakan suatu forum komunikasi antar orangtua dan anak penderita DM. Penyakit DM tipe-1 ini sangat membutuhkan insulin serta pengawasan yang ketat, sehingga diharapkan anggota dapat lebih baik dalam penanganan dan lebih percaya diri. Diharapkan peranan IKADAR lebih aktif agar lebih banyak anggota yang tercakup sehingga lebih banyak manfaat yang didapatkan.

\section{Daftar Pustaka}

1. Cooke D, Plotnick LP. Dalam: Pediatric endocrynology. Lippincott William \& Wikins; 2004.
2. Werther GA, Court JM. Diabetes and the adolescent. Melbourne, Australia: Miranova Publishers; 1998.

3. Noris AW, Wolfsdorf IJ. Diabetes mellitus. Dalam: Brook C, Clayton P, Brown R,penyunting. Clinical pediatric endocrinology. Edisi ke-5. Australia: Blackwell Publishing Ltd; 2005. hlm. 436-73.

4. Sperling MA. Diabetes mellitus. Edisi ke-2. Philadelphia, USA: Saunders; 2002.

5. Sperling MA, Diabetes mellitus in children. Pediatr Clin North Am. 2005 Des;52(6):345-60.

6. World Health Organization. Prevention of diabetes mellitus. Geneva:WHO Tech Rep Ser; 1994.

7. Arslanian S, Becker D, Drash A. Diabetes mellitus in the child and adolescents. Dalam: Kappy MS, Blizzard RM, Migeon CJ, penyunting. The diagnosis and treatment of endocrine disorder in childhood and adolescence. Edisi ke-4. Illinois: Charles C. Thomas; 1994. hlm. 961-1024.

8. Travis LB, Brouhard BH, Schreneir BJ. The clinical disease. Dalam: Travis LB, Brouhard BH, Schreneir BJ, penyunting. Diabetes mellitus in children and adolescents. Philadelphia: WB Saunders Company; 1987. hlm. 18-72.

9. Majalah IKADAR, New Sletter, No. I/Oktober 2003.

10. Asin SM, Rukman Y, Batubara JR. childhood onset of diabetes mellitus report on hospital cases. Pediatr Indones. 1990;30:209-12.

11. Tridjaja B, Batubara JR, penyunting. Konsesus Nasional Pengelolaan Diabetes Melllitus tipe-1 di Indonesia. Jakarta: UKK Endokrinologi IDAI; 2000 . 